\title{
ORIGINAL
}

\section{On the distribution of elastic fibers in the}

\section{filiform papillae of Suncus murinus}

\author{
Toshio Yamamoto, Shintaro Kondo and Hiroshi Nagai \\ Department of Oral Anatomy, Okayama University School of \\ Dentistry, Shikata-cho 2-5-1, Okayama 700, Japan \\ (Chief: Prof. Hiroshi Nagai) \\ 〔Accepted for publication: January 27, 1989〕
}

Key words: Suncus murinus/tongue / filiform papilla / elastic fiber

\begin{abstract}
The distribution of elastic fibers in the filiform papillae of 1, 2, 3, 4 and 5 week-old and 6 month-old Suncus (Suncus murinus; insectivora) was examined by both Weigert's resorcin-fuchsin method and ultrastructural means. In the adult Suncus (6 months old), elastic fibers in the connective tissue core of the papillae were aligned perpendicularly to the epithelial surface and formed a palisade-like structure which encircled the margin of each connective tissue core. This characteristic structure was restricted to the filiform papillae in the anterior half of the lingual dorsum. In the filiform papillae of the posterior half, elastic fibers were markedly reduced and the palisade-like structure was not present. This characteristic pattern of elastic fiber distribution was established by 3 weeks of age. These observation reveal a characteristic structure consisting of elastic fibers in the connective tissue core of the filiform papillae and the regional distribution of this structure in the tongue. This suggests that the function of the structure in the connective tissue core is to protect against mechanical stress in mastication. The regional distribution of this structure may reflect the difference of mechanical strength between the anterior and posterior of the tongue caused by tongue movement during mastication.
\end{abstract}

\section{Introduction}

Elastic fibers are one of the principal constituents of connective tissue and are predominant in tissues which require elasticity such as the wall of arteries, the alveoli of the lungs, skin, tendons and elastic ligaments ${ }^{1}$. In oral mucosae, elastic fibers are most abundant in the highly resilient lining mucosa such as the buccal mucosa, while the fibers are rare in non-distensible mucosa such as the masticatory mucosa ${ }^{2}$.

The dorsum of the tongue is covered with a specialized mucosa which forms lingual papillae, namely filiform, fungiform, foliate and circumvallate papillae. Among these papillae, filiform papilae function primarily in mastication $^{2)}$. With regard to the distribu- tion of elastic fibers in the lingual mucosa, Umeda et al. $^{3 \text { ' }}$ showed that elastic fibers ran regularly in a horizontal direction to the epithelial surface in rodents, while scattered in dogs and cats. However, there is no published report on the distribution of elastic fibers in the filiform papillae which are mechanically stressed during mastication. The purpose of the present study was to investigate the distribution of elastic fibers in the filiform papillae of the Suncus (Suncus murinus; insectivora).

\section{Materials and Methods}

For this study, 1, 2, 3, 4 and 5 week-old and 6 month-old Suncus were used and examined by both light and electron microscopy. For light microscopy, the tongues, after decap- 
itation, were collected, cut sagittally and fixed in buffered formalin. The tongues, after dehydration, were embedded in paraffin and sectioned in sagittal and horizontal directions. Sections were stained with hematoxylin-eosin or Masson-Goldners' trichrome stains in order to otserve histological features of the papillae. For detection of elastic fibers, Weigert's resorcin-fuchsin was employed. For electron microscopy, some animals were perfused via the left ventricle with $2 \%$ glutaraldehyde and $2 \%$ paraformaldehyde mixture$0.1 \mathrm{M}$ cacodylate buffer $(\mathrm{pH} 7.4)$. The tongues were cut into small pieces and post-fixed with $0.1 \mathrm{M}$ cacodylate-buffered $1 \%$ osmium tetroxide. Tissues were then dehydrated and embedded in Epon 812. Thin sections were stained with uranyl acetate and lead citrate $(\mathrm{Ur} \cdot \mathrm{Pb})$ for ultrastructural observations. For selective stain of elastic fibers, some thin sections were stained with tannic acid-uranyl acetate (TU) solution according to the method of Kajikawa et $a l^{4}$.

\section{Results}

The filiform papillae were distributed throughout the dorsum of the tongue and were conical in shape, tips with toward the posterior of the tongue. Connective tissue cores of the filiform papillae had a dome-shaped appearance (Fig. 1) in adult animals (6 monthold). No significant difference in size or height of the papillae was observed regardless of the region of the tongue as reported elsewhere ${ }^{51}$. However, marked differences regarding the distribution of elastic fibers were recognized between the filiform papillae in the anterior half and the papillae in the posterior half of the tongue. In the filiform papillae of the anterior half of the tongue, elastic fibers were aligned perpendicularly along the margin of the connective tissue core in a sagittal plane (Fig. 2 a). These fibers almost encircled the core to form a palisade-like structure (Fig. $2 \mathrm{~b}$ ). At the top and center areas of the core the fibers were sparsely distributed(Fig. 2 a, b). Elastic fibers were markedly decreased in the filiform papil. lae of the posterior half of the tongue and the characteristic structure seen in the anterior part was not observed in these papillae

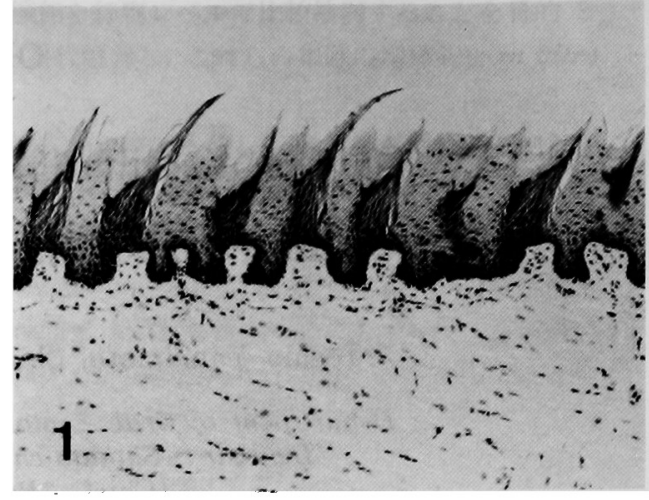

Fig. 1 Filiform papillae tips are bent toward the posterior. Connective tissue cores of the papillae are dome-shaped. H-E stain. $180 \times$

(Fig. 3). Electron microscopy also revealed elastic fibers in the filiform papillae of the anterior part of the tongue. They were distributed closely to the basal cell of the epithelium (Fig. $4 \mathrm{a}, \mathrm{b}$ ).

Young Suncus ( 1 to 5 week-old) were examined in order to determine at what age the elastic fibers formed the characteristic structure in the connective tissue core. Elastic fibers were rarely seen in lamina propriae mucosae, including connective tissue cores of the filiform papillae in 1 week-old animals (Fig. 5). In 2 week-old animals, a few fibers climbed the margin of the connective tissue cores (Fig. 6). More fibers were visible in each core and showed the same distribution pattern observed in adult animals by 3 weeks of age (Fig. 7). Elastic fibers in the cores of the filiform papillae of the anterior half of 4 and 5 weekold animals gradually increased in number.

\section{Discussion}

With regard to the distribution of elastic fibers in the proprial layer of the lingual dorsum, Umeda et al..$^{3)}$ reported that the fibers ran parallel to the epithelial surface in rodents and were scattered in dogs and cats, and the amount of the fiber was variable among the animals. In the present study employing the Suncus, elastic fibers were aligned perpendicularly along the margin of the connective tissue core of filiform papillae in sagittal sections, and in transversely cut sections 
T. Yamamoto et al. : Elastic fiber distribution in the filiform papillae

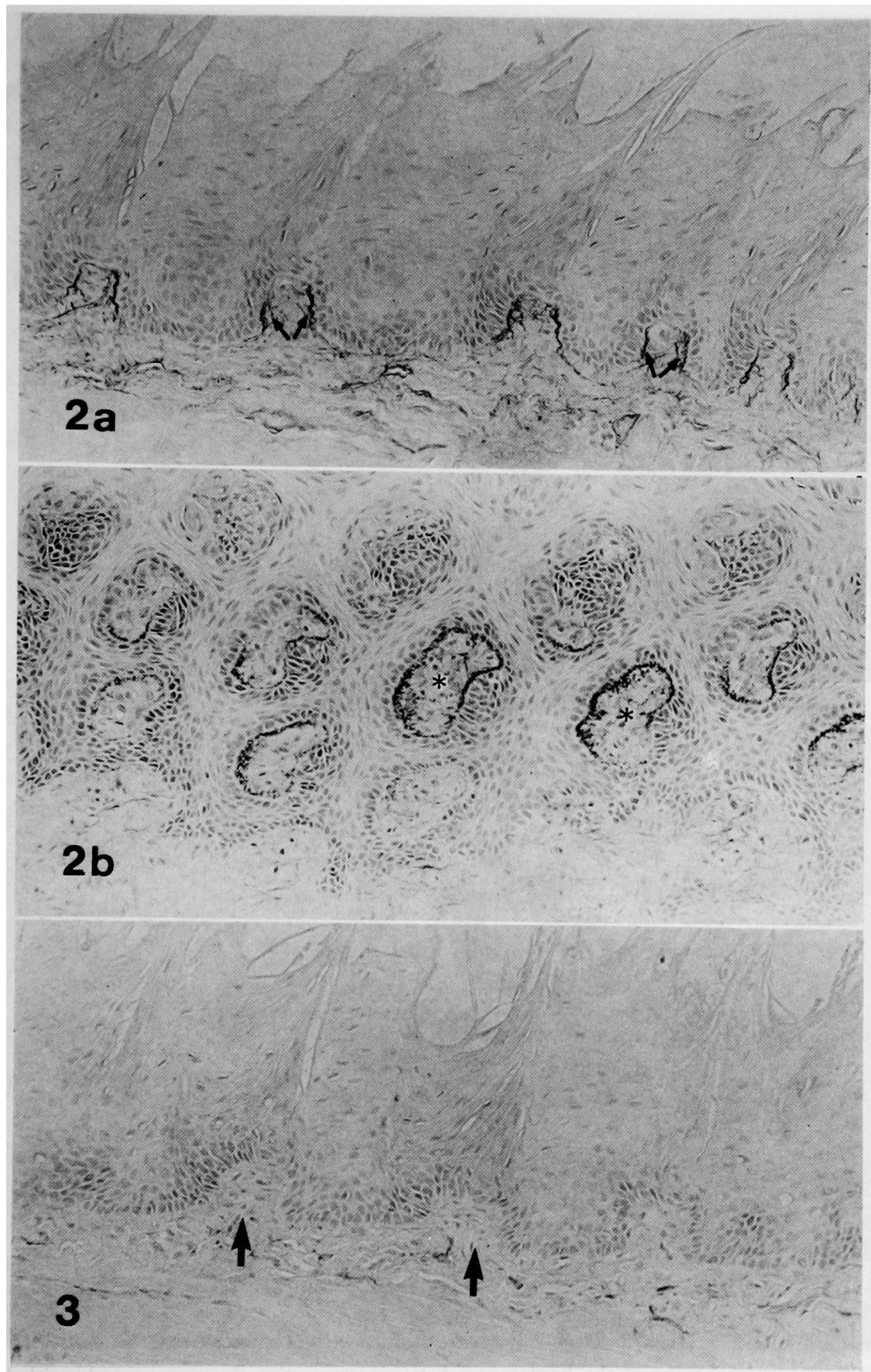

Fig. 2 Filiform papillae in the anterior part of the tongue stained by Weigert's resorcin. fuchsin. a: Elastic fibers climb along each margin of the connective tissue core (arrows). $190 \times$

b : A horizontal section of papillae. Elastic fibers almost encircle the periphery of connective tissue cores $(*)$. $190 \times$

Fig. 3 Filiform papillae in the posterior part of the tongue. Elastic fibers are hardly visible in the connective tissue cores (arrows). Weigert's resorcin-fuchsin stain. 190× 


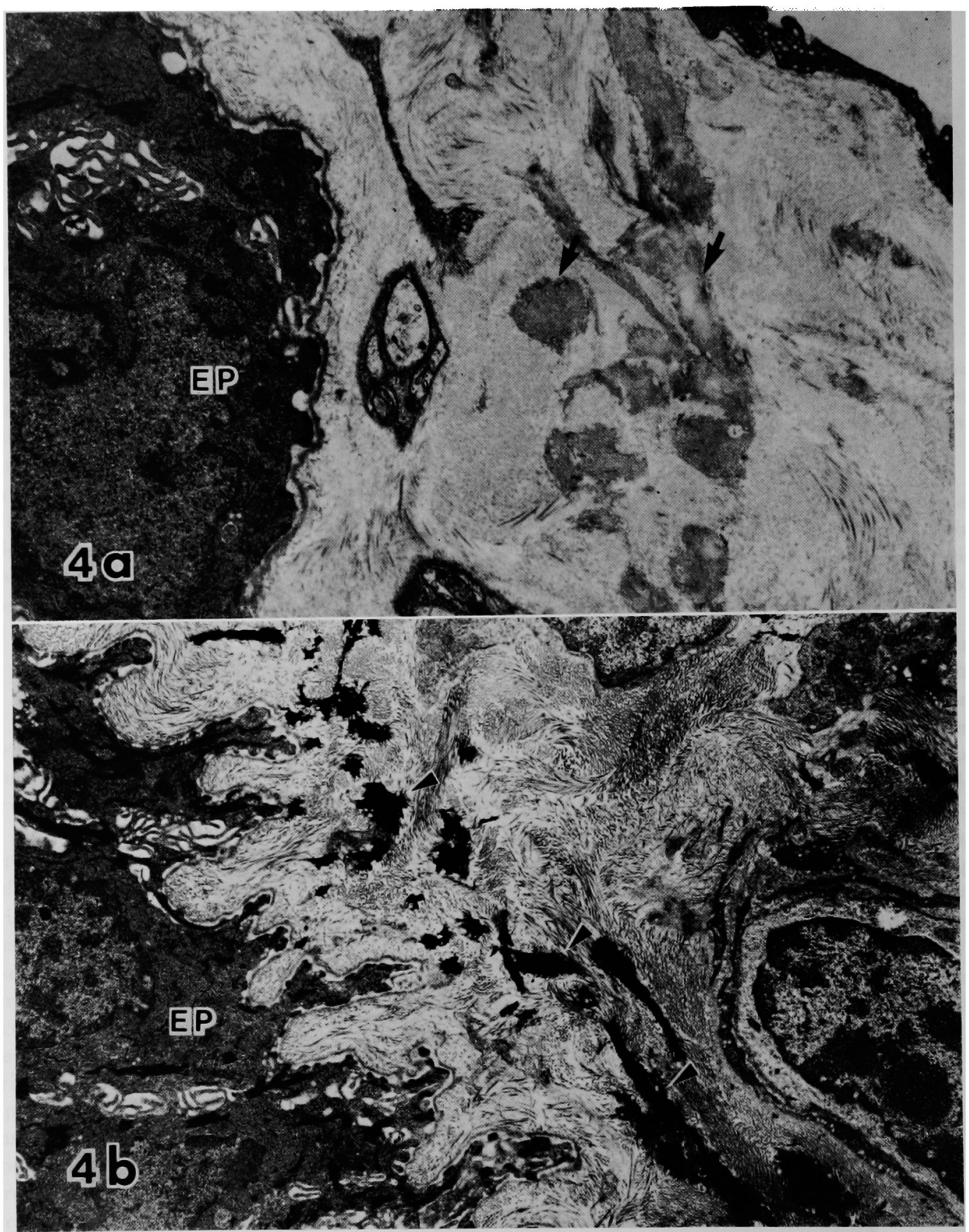

Fig. 4 Electron micrographs of the border area between connective tissue cores and epithelial cells in the filiform papillae of the anterior part of the tongue. a: Thick elastic fibers run near the basal cell of epithelium (arrows).

b: Elastic fibers selectively stained with TU solution show high electron density (arrowheads) and are mostly distributed at the periphery of the connective tissue core. EP; epithelial cell, a ; $13000 \times$, Ur-Pb stain. b; $7900 \times$, TU-Pb stain. 
T. Yamamoto et al. : Elastic fiber distribution in the filiform papillae

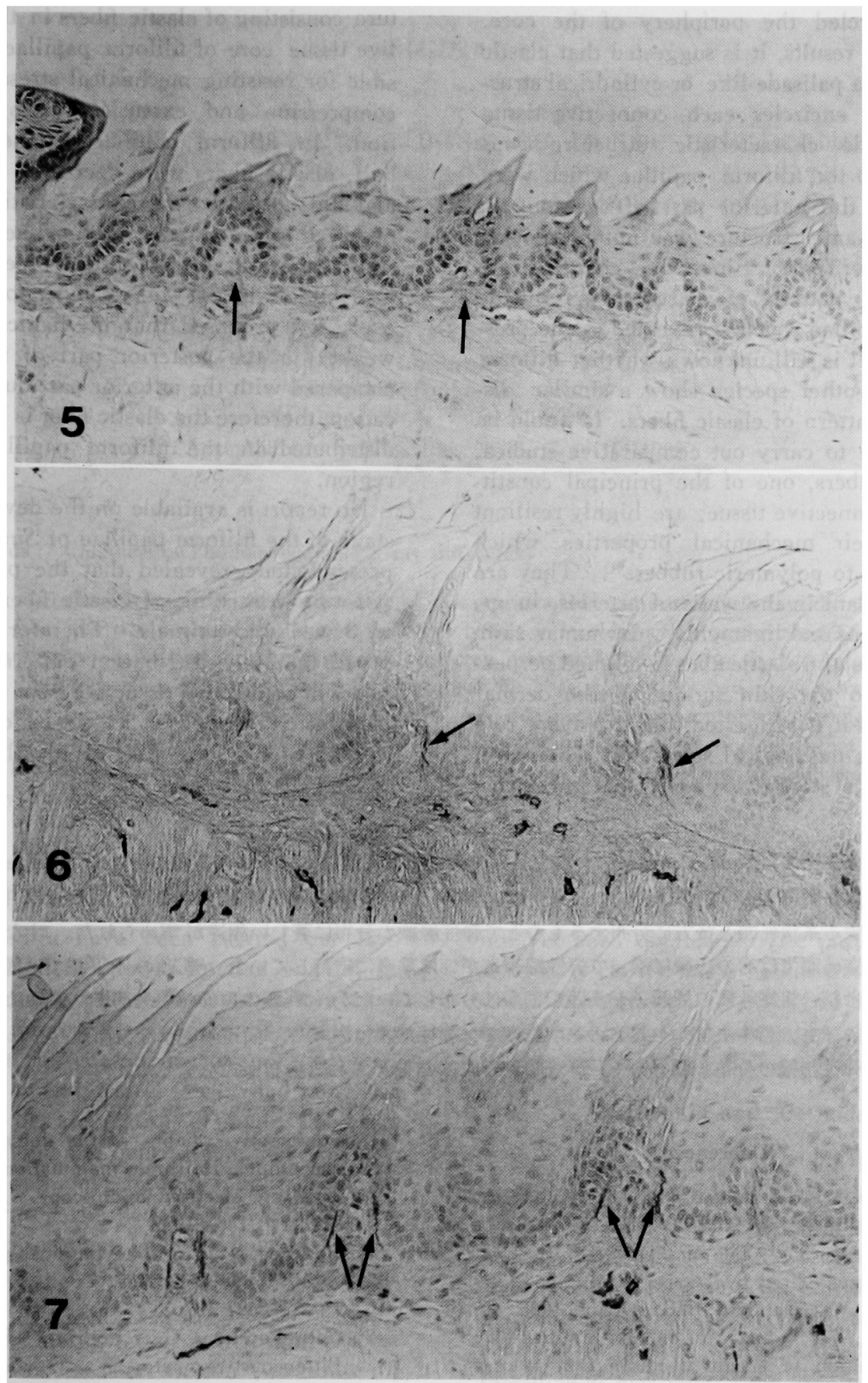

Fig. 5-7 Age related elastic fiber distribution. Weigert's resorcin-fuchsin stain.

Fig. 5 Filiform papillae of 1 week-old animal. The papillae are small and elastic fibers are rarely observed. Arrows indicate connective tissue cores. $190 \times$

Fig. 6 Filiform papillae of 2 week-old. Elastic fibers can be identified in the connective tissue core (arrows). $190 \times$

Fig. 7 Filiform papillae of 3 week-old. Elastic fibers are aligned along each margin of the connective tissue core (arrows). This pattern is the same as that observed in adult animals. $190 \times$ 
fibers encircled the periphery of the core. From these results, it is suggested that elastic fibers form a palisade-like or cylindrical structure which encircles each connective tissue core. This characteristic structure was restricted to the filiform papillae which were located in the anterior part of the tongue, while the same structure was not present in the posterior part. Since this characteristic distribution pattern of elastic fibers in the filiform papillae was first revealed in the present study, it is still unknown whether filiform papillae of other species show a similar distribution pattern of elastic fibers. It would be worthwhile to carry out comparative studies.

Elastic fibers, one of the principal constituents of connective tissue, are highly resilient due to their mechanical properties which are similar to polymeric rubbers ${ }^{6)}$. They are most abundant in the walls of arteries, lungs, skin, tendons and ligaments ${ }^{1}$. In human skin, for example, the elastic fiber is aligned perpendicularly to the skin surface in the dermal papilla and it is suggested that it plays a role in resisting mechanical stress ${ }^{7,8}$. Therefore, our findings strongly suggest that the struc- ture consisting of elastic fibers in the connective tissue core of filiform papillae is responsible for resisting mechanical stress including compression and extension during mastication. In filiform papillae of the posterior half, elastic fibers were decreased in number and did not show the characteristic structure observed in the anterior part. The functional significance of the difference of elastic fiber distribution is not fully understood. However, it is proposed that mechanical stress is weaker in the posterior part of the tongue compared with the anterior part during mastication, therefore the elastic fiber is less densely distributed in the filiform papillae of this region.

No report is available on the developmental stage of the filiform papillae of Suncus. The present study revealed that the palisade-like structure consisting of elastic fibers appeared in 3 week-old animals. Therefore it is proposed that the distribution pattern of elastic fibers in connective tissue cores of the filiform papillae is formed at 3 weeks of age and the amount of the fiber gradually increases to that of the adult.

抄録：スンクス (Suncus murinus; 食虫目) の舌の系状乳頭における弾性線維の分布をW eiger $\mathbf{t}$ の弾性 線維染色法と微細構造学的方法を用いて調へた。成体 ( 6 力月齡) の舌を観察すると, 舌のほぼ中央から前 方に分布する釆状乳頭と後方に分布するものとで弾性線維の分布に著しい相違が認められた。すなわち前者 の結合組織乳頭ではその辺縁に沿って弾性線維束がほぼ垂直に走行していた。乳頭の水平断では横断された 弾性線維は結合組織乳頭の周囲をとり囲むように分布していたが, 乳頭の頂部の中央部では線維は極めて乏 しかった。一方, 舌中央部から後方の系状乳頭では弾性線維は激減し, 前述のような分布はみられなかった。 加齢的に弾性線維の分布を調べると，3 週齢から成体で認められる分布様式を呈した。

\section{References}

1) Ross, R.: The elastic fiber. J. Histochem. Cytochem. 21 : 199-208, 1973.

2) Davis, W. L.: The oral mucosa. In Oral Histology, edited by Davis, W. L., pp. 179198, W. B. Saunders, Philadelphia, 1986.

3) Umeda, T., Tamari, Y. and Nishimura, M. : Distribution of elastic fibers in oral mucosa of mammals. J. Osaka Univ. Dent. Sch. 8 : $39-46,1968$.

4) Kajikawa, K., Yamaguchi, T., Katsuda, S. and Miwa, A.: An improved electron stain for elastic fibers using tannic acid. J. Electron Microsc. 24 : 287-289, 1975.

5) Iwasaki, S., Miyata, K. and Kobayashi, K.:
Comparative studies of the dorsal surface of the tongue in three mammalian species by scanning electron microscopy. Acta Anat. $128: 140-146,1987$.

6) Gosline, J. M.: The physical properties of elastic tissue. Int. Rev. Connect. Tissue Res. $7: 211-249,1976$.

7) Cotta-Pereira, G., Rodrigo, F. G. and Bittencourt-Sampaio, S.: Oxytalan, elaunin and elastic fibers in the human iskin. J. Invest. Dermatol. 66 : 143-148, 1976.

8) Tsuji, T.: Elastic fibers in the dermal papilla. Scanning and transmission electron microscopic studies. Brit. J. Dermatol. 102: 413-417, 1980. 